\title{
Ellipsis
}

2014

\section{for and to the glass smith}

trisha rezende

Follow this and additional works at: https://scholarworks.uno.edu/ellipsis

Part of the Poetry Commons

\section{Recommended Citation}

rezende, trisha (2014) "for and to the glass smith," Ellipsis: Vol. 41 , Article 19.

DOI: https://doi.org/10.46428/ejail.41.19

Available at: https://scholarworks.uno.edu/ellipsis/vol41/iss1/19

This Poetry is brought to you for free and open access by the Department of English and Foreign Languages at ScholarWorks@UNO. It has been accepted for inclusion in Ellipsis by an authorized editor of ScholarWorks@UNO. For more information, please contact scholarworks@uno.edu. 


\title{
for and to the glass smith
}

\author{
trisha rezende
}

sometimes i pretend

i'm enlightened like strangers don't make me

an Atlas like on the darkest street i'm the one lamppost

alive at 3 a.m. like $i$ know how to mend

anything but a torn dress needle and thread

can't fix everything i know better

how to pour peroxide over skin scrapped

raw let it burn until there's no burn left but then

like $\mathrm{i}$ belonged to the wrong man beside me his wrong arm

around me i entered the heat

to find you looking into the hell

of a furnace the crucible of molten glass

at the end of your gaze the only thing worth your gaze

and $i$ understood purpose

or was it love or was it the purpose of love

to gather and twirl and gather and twirl

as if breaking wasn't an option but mending was

inevitable as if the shatter of falling out of love meant less

because you knew that more could be gathered

and twirled twirled twirled as if the punty wasn't

the most dangerous baton ever wielded

but a weapon that healed better

than meaningless sex and midnight

bourbon you accidental teacher

you heart on fire let us gather

around you daydream of glass dragons

and fear not their hot breath 